\title{
Framing Conflict Mediation in the Context of Teacher Training: A Scoping Review of the Literature Between 2000 and 2020
}

\author{
Margarida Alves ${ }^{1}$ and Elisabete Pinto da Costa ${ }^{2}$ \\ 1 Escola Superior de Educação do Instituto Politécnico de Viana do Castelo, Portugal | \\ amargarida@ese.ipvc.pt; https://orcid.org/0000-0001-5243-9558 \\ 2 Universidade Lusófona do Porto, Portugal | elisabete.pinto.costa@gmail.com| \\ https://orcid.org/0000-0002-6255-4135
}

\begin{abstract}
A scoping review from 2000 to 2020, in a qualitative approach, were analyzed in order to provide a synthesis of the empirical issues concerning conflict mediation in schools in the context of teacher education, and to investigate the extent to which empirical research has provided evidence on key elements that are crucial to develop conflict mediation skills among teachers. A scoping review, on Scopus and B-on online databases, was made using nine inclusive criteria. The results showed that the number of publications is stable throughout the years. Seven journals published studies about this subject. Two continents are represented in the reviewed studies. They were mostly on-site and qualitative research and focus the mediation as a method of conflict resolution, and as a tool to introduce initial learning-to-teach experiences. There are a few empirical studies in which conflict mediation and its impact on teacher education is sufficiently explored. A thematic overview of reported outcomes suggested that although mediation is perceived as positive and encourages emotional, cognitive, and moral learning, stimulating pre-service teachers' reflective thinking, teachers identify a deficiency when it comes to their training.
\end{abstract}

Keywords: scoping review, school mediation, teacher education.

\section{Theoretical Background}

Since the 90's, the interest in school mediation has increased given that school has the aim to educate students based on diversity, civic rights, culture, and solidarity.

Despite the importance of the conflict mediation during initial teacher education, pre-service teachers appear unprepared to deal with its complex reality and initial teacher education institutes appear to favour the development of cognitive aspects of professional identity over the social and emotional aspects (Romanova et al., 2019). While previous conflict mediation reviews allow us to understand the concept of conflict mediation, there has been a lack of focus on how teachers deal with conflicts. Concerning this matter,

"we are still faced with few scientific studies with regard to the continuous training of teachers in conflict mediation and on the teacher's role as mediator, as well as on the contribution of conflict mediation in the acquisition of socio-educational skills" (Costa, 2020, p. 3).

Conflict mediation is a popular research topic, often related to peace education, post-war contexts, diversity, global education, and restorative justice. Given that school is inherently a space of coexistence, and that schools have been facing and adapting to different and evolving social challenges (Costa \& Sá, 2019), it is expected to arise some conflicts when teachers are not well prepared to deal with historical, cultural, context and economic diversity. Mediation can be described as "a win-win process, with a focus on disputants who design their mutually satisfactory conflict resolution" (DeVoogd et al., 2016, p. 279). In school context, mediation by focusing on interpersonal relations, has shown a great pedagogical potential, especially through prevention (Costa et al., 2018).

Although positive findings have been reported concerning conflict mediation strategies, little has been written concerning how preservice teachers should address conflict and moreover, how they have been trained to deal with such pressing matters. Several authors 
claimed that initial teacher education curricula is often focus solely on content and cognitive knowledge and has proven to be insufficiently prepared to teach preservice teachers how to deal with diversity and challenging school contexts (Kharlanova et al., 2020; Morueta \& Vélez; 2015; Jovanovic et al., 2014). As the concept of conflict is often identified as negative, it is important to understand that a conflict is also an opportunity to learn and to develop new levels of empathy, that conflicts will naturally exist in school contexts and that conflicts are not, in nature, nor constructive or destructive events, it depends on the negotiation process and the final outcome (Caputo et al., 2019).

When asked about which essential skills a teacher needs to develop, pre-service teachers identified conflict mediation strategies as a requirement, and specially, they claim they are not familiarized with which theoretical framework they should follow when dealing with conflicts (Kharlanova et al., 2019; Basqueira \& Azzi, 2014; Horsley \& Bauer, 2010). Lastly, it is important to uncover how mediation has been used in school contexts (Costa et al., 2018).

\section{Methodology}

This study pursues the following research question: What can we learn from research on conflict mediation in schools in the context of initial teacher training published in EBSCOhost and Scopus databases? The purpose of this scoping review, which reported the use of qualitative methods to a comprehensive synthesis of literature (Munn et al., 2018), is to provide a synthesis of the empirical issues concerning conflict mediation in schools in initial teacher training and investigate the extent to which empirical research has provided evidence on key elements that are crucial to develop conflict mediation skills among teachers.

The scoping review presented in this study focused on related publications from January 2000 to May 2020. In doing so, the aim is to update the reported process of conflict mediation in schools in teacher training. By providing clear information about the methodology used, our intention is to time frame the literature. The intention is also to delve into each study, beyond summarizing the literature, to identify reported similarities and differences of the conflict mediation in schools during teacher education. This will potentially aid those responsible for teacher education (i.e., teacher educators and cooperating teachers in schools) to effectively support and facilitate conflict mediation skills among future teachers since school is a space for socialization.

Scoping reviews are more than non-systematic reviews. They entail conceptual mapping to assess potential size and scope of existing research literature and aim to identify the nature and extent of research evidence to address complex and exploratory research questions (Anderson et al., 2008; Grant \& Booth, 2009). A scoping review entails five different and subsequent stages:

- identifying the research question,

- identifying relevant studies,

- study selection,

- charting the data, and

- collating, summarizing and reporting the results (Arksey \& O'Malley, 2005).

The SCOPUS and B-ON online databases were searched using the following keywords:

- school mediation

- conflict mediation

- teacher training

- teacher education

- school placement

- practicum 
The fields of research used were Abstract, Subject and Title. The inclusion criteria were:

- studies published in peer-reviewed scientific journals,

- studies published between January 2000 and May 2020,

- empirical studies,

- availability of full-text,

- written in English,

- written in Portuguese,

- written in Spanish, and

- focusing on conflict/school mediation in teacher training.

Search controllers were set to ensure that the search retrieved only full-text peer-reviewed empirical studies published in English, Portuguese, and Spanish. The initial search was independently conducted by one individual and resulted in the identification of 70 studies. After removing five duplicates using the EndNote X9 software, the title, abstract and subject of the remaining 65 studies were screened to assess their relevance using the inclusion criteria, resulting in the exclusion of 40 studies. Search parameters were strictly applied to the remaining 25 full-text studies. Studies that did not explore conflict mediation in school context in-depth and did not contain any outcomes related to teacher education, were excluded. The final sample constituted seven empirical research studies that were thoroughly reviewed. A PRISMA flowchart (Moher et al., 2009) is used to demonstrate the review process.

A descriptive information (author, year, journal, country) concerning each study was provided to map the empirical studies included in the scoping review. The in-depth analysis was based on a synthesis of the definition of mediation or, where a definition was not provided, an authors' point of view concerning mediation was delivered, main data collection tools, and remarkable outcomes. Study categorization into themes was double checked.

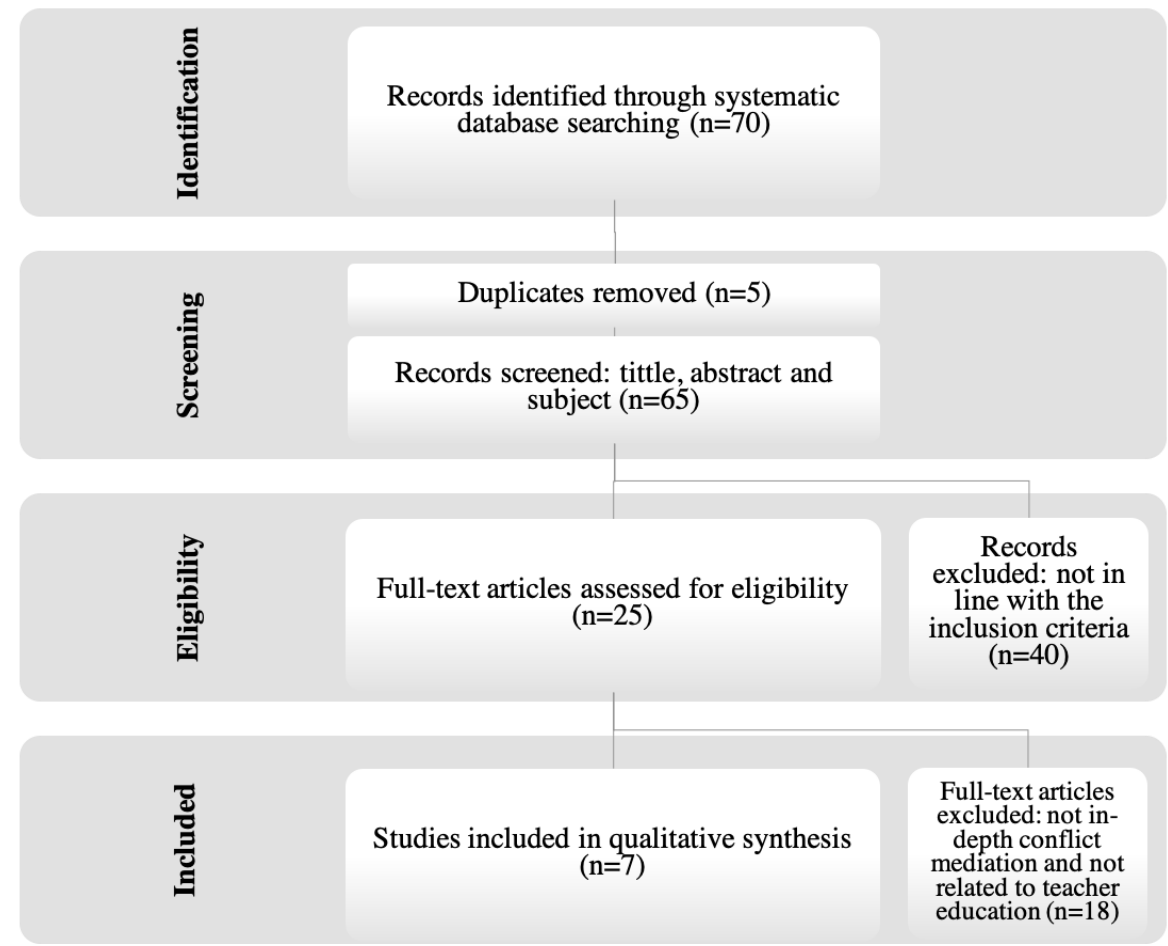

Fig. 1. Scoping review PRISMA flowchart. 


\section{Results}

Results from eligible articles will be qualitatively synthesized using the framework synthesis approach. First, general information on the number of publications per year (2000-2020), per teaching area, per journal and per country is shared. The study then focuses on the two recurring themes: 1) mediation as a method of conflict negotiation, and 2) mediation as a tool to introduce initial learning-to-teach experiences to pre-service teachers.

\subsection{Descriptive Results}

The number of publications is very stable throughout the years, with only one publication in the most part of the years. Interestingly, there is a 5-year gap of publications between 2005 and 2010. With a small rise in publications in 2016, there was a decrease again in 2020, likely to be affected by the search for studies included in this study ending in May of this year. It remains to be seen if any other papers will be published this year. Seven journals published studies on conflict mediation during teacher education. It is noticeable that the majority of journals had only published one conflict mediation related study between 2000 and 2020. During that timeframe there were no special issues concerning conflict mediation in the school context in the analyzed journals. Only two continents (America and Europe) are represented when considering where the data for the studies were gathered. Again, it is interesting to note that a critical mass of such publications is evident mainly in one country, USA (the other countries were Brazil, Spain and Ukraine).

\subsection{Mediation as a Method of Conflict Resolution}

Mediation as a method of conflict resolution was acknowledged in three of the seven research studies. The data of these three studies was gathered on two different continents, America and Europe. One study was qualitative, the second, quantitative, and the third study did not define the main data collection tools. Here, qualitative methods entailed students' narratives, and quantitative methods entailed the application of a survey. Data were collected mostly in a single country. While there appeared to be differences between the studies in terms of the type of methods used, no obvious distinction was found between the general findings as a result of the methods used. Similar and complementary characteristics of conflict mediation and outcomes for teacher education were observed across the studies in the same category, regardless of the chosen methods and number of participants.

Table 1. Chronological overview of the studies concerning mediation as a method of conflict resolution.

\begin{tabular}{|c|c|c|c|}
\hline $\begin{array}{l}\text { Author, year and } \\
\text { context }\end{array}$ & $\begin{array}{c}\text { Mediation definition/seen } \\
\text { as... }\end{array}$ & $\begin{array}{c}\text { Main data } \\
\text { collection tools }\end{array}$ & Remarkable outcomes \\
\hline $\begin{array}{l}\text { Yssel, Beilke, Church } \\
\text { and Zimmerman } \\
\text { (2001) } \\
\text { USA }\end{array}$ & $\begin{array}{l}\text { Mediation is a method of } \\
\text { conflict resolution that utilizes } \\
\text { a third-party mediator in order } \\
\text { to settle a dispute between } \\
\text { two parties. Elements of } \\
\text { school mediation programs } \\
\text { include the use of problem- } \\
\text { solving skills that can lead to } \\
\text { a win-win situation rather than } \\
\text { a compromise in which one } \\
\text { person feels that he or she } \\
\text { has lost. }\end{array}$ & NA & $\begin{array}{l}\text { Preservice teachers } \\
\text { should participate in } \\
\text { experiential learning } \\
\text { opportunities, } \\
\text { developing mediation } \\
\text { skills, and designing and } \\
\text { implementing proactive } \\
\text { strategies. The CoRE } \\
\text { (conflict resolution in } \\
\text { education) model offers } \\
\text { teachers conflict } \\
\text { resolution/per mediation } \\
\text { skills in a four-level } \\
\text { approach: foundational } \\
\text { knowledge, integration, } \\
\text { contextual, and }\end{array}$ \\
\hline
\end{tabular}




\begin{tabular}{|c|c|c|c|}
\hline & & & $\begin{array}{l}\text { implementation. For } \\
\text { preservice teachers to } \\
\text { become skilled in } \\
\text { mediation, the following } \\
\text { key components should } \\
\text { be addressed: self- } \\
\text { exploration, theory, } \\
\text { principles, and } \\
\text { information, skill } \\
\text { building, the mediation } \\
\text { process, and simulated } \\
\text { practice. }\end{array}$ \\
\hline $\begin{array}{c}\text { Lane-Garon, Ybarra- } \\
\text { Merlo, Zajac and } \\
\text { Vierra } \\
\text { (2005) } \\
\text { USA }\end{array}$ & $\begin{array}{c}\text { Mediation itself contributes to } \\
\text { adaptive human development } \\
\text { in that it provides a model for } \\
\text { considering another's } \\
\text { diverging shared problem and } \\
\text { experiencing satisfaction with } \\
\text { a mutually designed solution } \\
\text { (Lane-Garon \& Richerdson, } \\
\text { 2003). }\end{array}$ & $\begin{array}{l}\text { Analysis of pre-to- } \\
\text { post changes } \\
\text { standardized test } \\
\text { scores Survey }\end{array}$ & $\begin{array}{l}\text { Mediation program } \\
\text { participation by a } \\
\text { preservice teacher, led } \\
\text { her to state that through } \\
\text { mediation, students } \\
\text { understand that she } \\
\text { cared about them, } \\
\text { taught her to listen and } \\
\text { students saw her as a } \\
\text { role model. }\end{array}$ \\
\hline $\begin{array}{c}\text { Koshmanova and } \\
\text { Ravchyna } \\
\text { (2010) } \\
\text { Ukraine }\end{array}$ & $\begin{array}{l}\text { Mediation as a process of } \\
\text { negotiation promoted by a } \\
\text { third, neutral side (or } \\
\text { mediator) in which } \\
\text { participants look for solutions } \\
\text { for conflicts that arise among } \\
\text { them. }\end{array}$ & $\begin{array}{l}\text { Students' narratives } \\
40 \text { prospective } \\
\text { teachers }\end{array}$ & $\begin{array}{l}\text { All the students valued } \\
\text { the significance of } \\
\text { mediation for gaining } \\
\text { experience to engage in } \\
\text { a dialogue with people } \\
\text { with opposite points of } \\
\text { view and that the } \\
\text { changes that occurred in } \\
\text { students' attitudes to } \\
\text { socially meaningful } \\
\text { activity were progressing } \\
\text { in stages. The } \\
\text { experiment confirmed } \\
\text { the positive influence of } \\
\text { mediation on the } \\
\text { formation of teacher } \\
\text { candidates' attitudes } \\
\text { toward socially } \\
\text { meaningful activity as a } \\
\text { civic value. }\end{array}$ \\
\hline
\end{tabular}

Findings revealed it is fundamental for pre-service teachers to learn, implement and reflect upon mediation strategies since the school context is characterized by ever-changing contexts with equally challenging conviviality circumstances between actors from all school communities. Yssel et al. (2001) stated that in order for pre-service teachers to become skilled at mediation, the following key components should be addressed: self-exploration, theory, principles, and information, skill building, the mediation process, and simulated practice. Pre-service teachers should be allowed to explore their thoughts concerning conflict since they are often taught that conflict is inherently negative and have almost nonpositive examples on how to explore the conflict mediation in a constructive perspective. Since pre-service teachers are discovering who they are and constructing their professional identity, it can be stressful to address these questions. Regarding mediation process, Yssel et al. (2001) stated that it is constituted by four distinctive phases: premeditation meetings, open questioning or storytelling, mediated interaction, and, finally, problem-solving phase. Pre-service teachers should practice the different stages of a mediation process and inherent tasks through role playing. In so being, the authors advocate the implementation of a program during teacher education, where students learn and practice mediation skills throughout their initial training, developing from freshman year to senior year.

The need for practice is also acknowledged by Lane-Garon et al. (2005) stating that while participating in a mediation process it is possible for pre-service teachers to act as role models for their students. Pre-service teachers also pointed out that in order to be a good 
mediator, one had to listen carefully; a characteristic also needed to become an excellent teacher. The way one teacher engaged in the mediation process led the students to become more respectful since he was making a great commitment with his personal life and their learning process. The point of view defended by the authors is closely linked to developing peaceful ways to resolve a conflict that, when implemented holistically, will affect learners in different ways, such as knowledge and communication about conflict substance, relationship between parties, and the process of constructive conflict management.

Also intimately related with peace education is the perspective of mediation stated by Koshmanova and Ravchyna (2010), namely because of the historical and cultural past of Ukraine, deeply marked by war. In such realities, mediation can be seen as a fundamental strategy to be used in a school context, since the aim is to develop a democratic relationship among the school community. Mediation engagement by pre-service teachers proved to have a positive influence on their formation process since they started to have gain experience in dialogue with persons with different points of view by finding common ground for mutual agreement. Mediation provided a methodology to overcome disagreements and to build experience of constructive communication by the pre-service teachers.

\subsection{Mediation as a Tool to Introduce Initial Learning-to-Teach Experiences}

Key elements regarding mediation as a tool to introduce initial learning-to-teach experiences to pre-service teachers were discussed in four studies. The data of these four studies were gathered in the same two continents (America and Europe) with most of the data collected in America. The reviewed studies were small-scale and qualitative. In these cases, qualitative methods entailed microteaching simulation, interviews, ethnography, written reflections, field observation and audio-recorded debriefs. Only one of the four studies draws on 'in situ' methodologies such as observation and ethnography. Among the studies reviewed in this category, there was one case study. Data were collected in a single country, with one study presenting conclusions based on data collected in two different countries.

Table 2. Chronological overview of the studies concerning mediation as a tool to introduce initial learning-to-teach experiences.

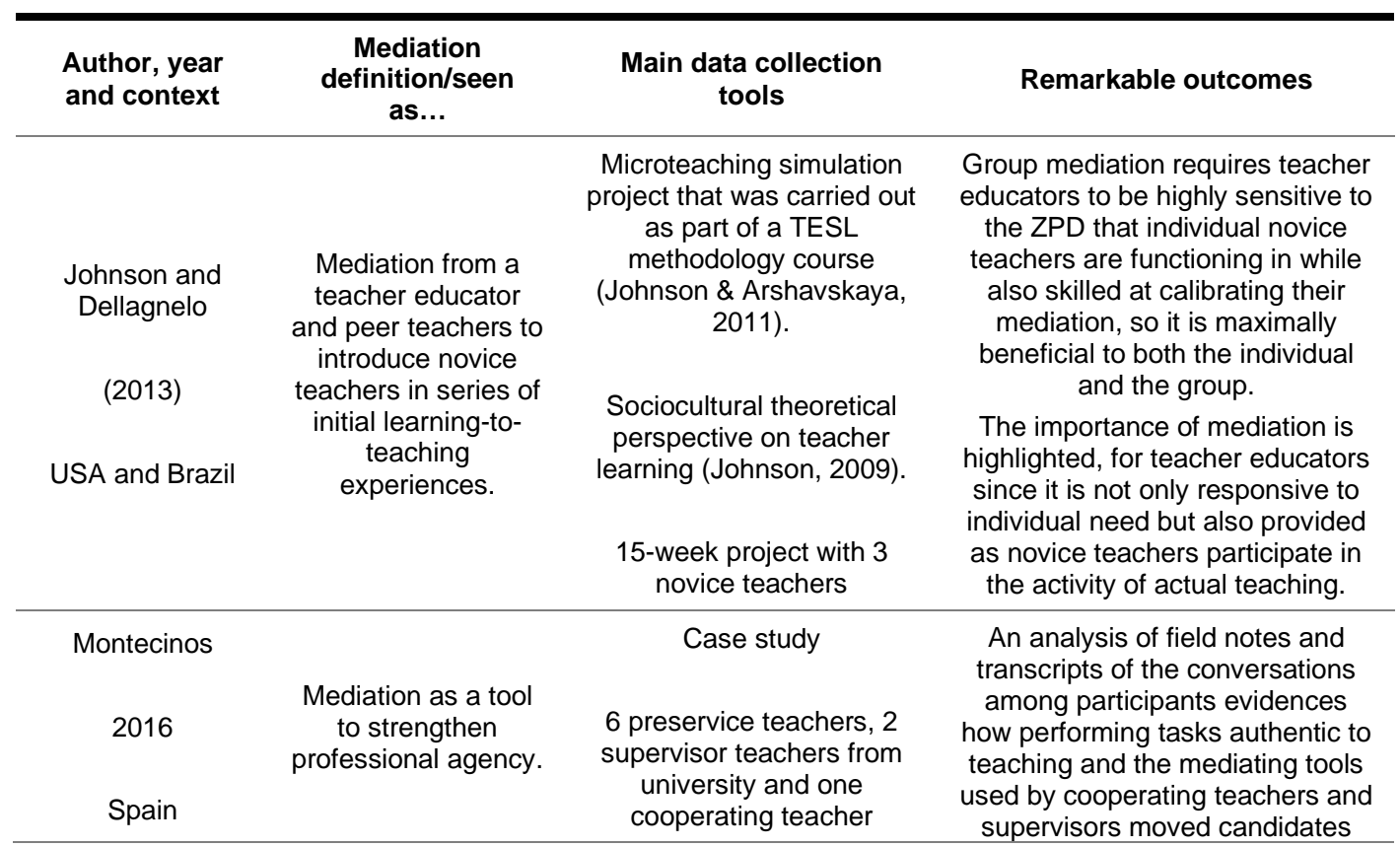




\begin{tabular}{|c|c|c|c|}
\hline & & & $\begin{array}{l}\text { from a focus on their teaching to a } \\
\text { concern for how much their } \\
\text { students were learning. }\end{array}$ \\
\hline $\begin{array}{c}\text { Willey and } \\
\text { Magee } \\
(2016) \\
\text { USA }\end{array}$ & $\begin{array}{l}\text { Mediation as the } \\
\text { process by which the } \\
\text { more experienced } \\
\text { person facilitates the } \\
\text { development of } \\
\text { more sophisticated } \\
\text { mental processes, } \\
\text { which includes the } \\
\text { way learners (i.e., } \\
\text { prospective } \\
\text { teachers) can think } \\
\text { about or talk about a } \\
\text { concept in more } \\
\text { nuanced or abstract } \\
\text { ways. }\end{array}$ & $\begin{array}{l}\text { Ethnographic study } \\
\text { Artifacts and dialogue } \\
\text { pertaining to instructors' } \\
\text { iterative thinking about } \\
\text { mediating prospective } \\
\text { teachers' learning from } \\
\text { clinical experiences. } \\
\text { Conversations around } \\
\text { student teaching lesson } \\
\text { enactment. }\end{array}$ & $\begin{array}{l}\text { Focusing attention on the } \\
\text { intentional design and } \\
\text { assessment of the mediational } \\
\text { activities coupled with clinical } \\
\text { experiences leads to more } \\
\text { nuanced understandings and } \\
\text { enactments of culturally relevant } \\
\text { teaching among prospective } \\
\text { teachers; and clinical experiences } \\
\text { afford prospective teachers' } \\
\text { abundant opportunities to shape } \\
\text { complex identities as urban } \\
\text { teachers. Specifically, we found } \\
\text { that clinical experiences and } \\
\text { corresponding mediational } \\
\text { activities support prospective } \\
\text { teachers' understanding of } \\
\text { families of colour, allow them to } \\
\text { recognize and address } \\
\text { problematic schooling practices, } \\
\text { and strengthen prospective } \\
\text { teachers' otherwise fragile critical } \\
\text { consciousness. }\end{array}$ \\
\hline $\begin{array}{l}\text { Guggenheim } \\
\text { (2019) }\end{array}$ & $\begin{array}{l}\text { Mediation as a tool } \\
\text { for helping } \\
\text { preservice teachers } \\
\text { to approach } \\
\text { literacies as political, } \\
\text { learn with children } \\
\text { who have different } \\
\text { cultural, linguistic, } \\
\text { and racial identities } \\
\text { than them, and } \\
\text { navigate the } \\
\text { continual becoming } \\
\text { inherent in equity- } \\
\text { oriented practice }\end{array}$ & $\begin{array}{l}\text { Audio-recorded weekly } \\
\text { debriefs with university } \\
\text { partners (preservice } \\
\text { teachers). } \\
\text { Semi-structured interviews } \\
\text { with university partners } \\
\text { (preservice e teachers). } \\
\text { Fieldnotes from university } \\
\text { partners (preservice } \\
\text { teachers) and two } \\
\text { facilitators. }\end{array}$ & $\begin{array}{l}\text { Participating in socio-critical } \\
\text { literacy can support reaching } \\
\text { toward equity in partnership with } \\
\text { children. Wobbling can be } \\
\text { supported within a robust teacher } \\
\text { education program with mediation } \\
\text { by university instructors and site } \\
\text { facilitators across a practicum site } \\
\text { and connected university course. } \\
\text { Wobbling is not finished when } \\
\text { preservice teachers become } \\
\text { practicing teachers but rather is } \\
\text { something that will hopefully be } \\
\text { carried throughout their careers } \\
\text { as they learn to sense, negotiate, } \\
\text { and mediate the new wobbles that } \\
\text { are sure to come. }\end{array}$ \\
\hline
\end{tabular}

Findings highlighted that in teacher education, mediation is often used in order to portray helping pre-service teachers moving from a rather simplistic perspective of teaching into more complex thoughts and to reflect upon their learning process, accommodating new teacher profession artefacts.

Johnson and Dellagnelo (2013) highlighted peer mediation importance so that pre-service teachers can experience actual teaching and attribute meaning to each moment. Mentoring processes can help pre-service teachers make sense of professional identity transformations and understand under what conditions these transformations occur.

In a study carried out by Córtez and Montecinos (2016) mediation is seen as a tool to enhance pre-service teacher agency, framing the triad made by pre-service teacher, cooperating teacher and university supervisor. Once again, peer mediation is key on developing pre-service teacher identity. Mediation allowed pre-service teachers to change focus from their teaching and refocus on how much and how their students were learning and act in conformity. Willey and Magee (2016) focused their attention on mediation as a way for pre-service teachers to develop more conscious attitudes towards problematic schooling practices and to enrich their critical consciousness regarding, for example, families of colour.

This perspective is also shared by Guggenheim (2019), as mediation is a tool for helping pre-service teachers to approach literacies as political and to deal with students with 
different cultural, linguistic, and racial identities. Mediation will help pre-service teachers to negotiate their positions during school placement, by raising awareness concerning different power relationships and civic learning.

\section{Discussion}

While two continents (America and Europe) are represented in the reviewed studies, there appears to be an overreliance on studies from the USA. The fact that conflict mediation in teacher education studies are mostly single-sited and enacted in the same countries may constrain researchers from comparing and understanding different realities. Although conflict arises daily in school context, there is a lack of studies reliant on classroom/school observation, ethnography or the tracking of daily activities, routines, behaviours, socialization within school context and did so over a prolonged period. This suggests a lack of attention to such data collection tools and assessment in schools as suggested by Hakvoort et al. (2019). The analysis conveyed that in most studies, pre-service teachers' own perception of conflict mediation was not explored. The study carried out through 'in situ' methods relied on more than one tool to collect data, highlighting the need to cross reference data from more than one source to understand a concept as complex as that of conflict mediation in schools.

Few studies draw their attention to mediation as a skill to be developed by pre-service teachers and integrated in teacher education curricula. This was surprising, given that several authors acknowledge school as a crucial context for socialization (Costa \& Sá, 2019; Costa et al., 2018; Martins et al., 2016). While there are consistencies between the perspectives of the different authors, there appears to be sufficient common points to frame conflict mediation in teacher education. Not only does mediation encourage emotional, cognitive and moral learning but also, it stimulates pre-service teachers' reflective thinking about inclusion and associated values and empathy towards different realities and prepare them to deal with inherent school coexistence (Costa \& Sá, 2019; Ibarrola-García et al., 2017).

At the same time, by teaching pre-service teachers mediation skills, they will be recognized as role models by students and will be able to teach them how to mediate their own conflicts through self-regulation, contributing to a peaceful school environment (Blunk et al., 2017). The importance of reflection is foregrounded in several studies as a strategy that can facilitate conflict mediation since it represents a way to attribute meaning to the lived experiences during school placement and to questioning taken-for-granted assumptions (Torrecilla et al., 2017). Through reflection, pre-service teachers identified important themes for teaching practice development, shared concerns, and doubts, realized their emotions and developed strategies to cope with different teaching-related challenges. By providing spaces and times for pre-service teachers to reflect and engage in mediation role playing, cooperating teachers, and initial teacher education programs are also granting preservice teachers an active voice.

Universities and schools should work closely in order to assist pre-service teachers dealing with conflict mediation, with many studies concluding that initial teacher education programs have a significant influence when negotiating conflicts. Initial teacher education programs should consider pre-service teachers' prior beliefs and experiences, grant opportunities for pre-service teachers to negotiate tensions and for pre-service teachers to develop strategies for socio-moral and civic learning. Sadly, the studies shared minimal contextual and practice-related information on initial teacher education programs. 


\section{Conclusion}

There are few empirical studies in the last twenty years in which conflict mediation and its impact on teacher education is sufficiently explored. The reviewed studies were mostly one-site and qualitative. There is a necessity to reflect on how data is collected to study conflict mediation since only one study enacted in-situ methodologies, with potentially more substantial results arising from observation and ethnography approaches. Similarly, data collected in different contextual and cultural environments can deepen our knowledge about conflict mediation in teacher education. Conflict mediation skills entails the engagement in cognitive learning, interacting with different socializing factors and experiencing various emotions as the pre-service teachers develop conflict resolution skills. Collaborative work, peer mediation, constructively critical teacher education courses, mentoring, observation, role playing, reflections, and the construction of a discursive space seem to be adequate strategies to help pre-service teachers developing conflict mediation skills.

Although there is a growing interest in understanding conflict mediation in the school context, the conclusions of many studies related to this interest are not always developing or challenging the reality experienced by pre-service teachers on initial teacher education programs. There is a danger in perceiving conflict mediation skills as a natural process that will occur even without guidance. It is essential that initial teacher education programs ensure that conflict mediation is intentionally oriented with the purpose of helping preservice teachers to become the type of teacher they strive to become.

Finally, this qualitative approach analysis aims to generate results that are useful and relevant for researchers and education decision-makers, in order to inform a research agenda and to more effectively influence policies and practices on teacher education.

\section{References}

Anderson, S., Allen, P., Peckham, S., \& Goodwin, N. (2008). Asking the right questions: scoping studies in the commissioning of research on the organisation and delivery of health services. Health Research Policy And Systems, 6, 7. https://doi.org/10.1186/1478-4505-6-7

Arksey, H., \& O'Malley, L. (2005). Scoping studies: Towards a methodological framework. International Journal of Social Research Methodology, 8(1), 19-32. https://doi.org/10.1080/1364557032000119616

Basqueira, A., \& Azzi, R. (2014). Como futuros professores vislumbram o ensino? [How future teachers view education?]. Psicologia: Ensino \& Formação, 5(2), 2-18. http://pepsic.bvsalud.org/scielo.php?script=sci_arttext\&pid=S217720612014000200002\&lng=en\&tIng=en

Blunk, E., Russell, E., \& Armga, C. (2017). The role of teachers in peer conflict: implications for teacher reflections. Teacher Development, 21(5), 597-608. https://doi.org/10.1080/13664530.2016.1273847

Caputo, A., Marzi, G., Maley, J., \& Silic, M. (2019). Ten years of conflict management research 2007-2017: An update on themes, concepts and relationships. International Journal of Conflict Management, 30(1), 87-110. https://doi.org/10.1108/IJCMA-06-2018-0078

Córtez, M., \& Montecinos, C. (2016). Transitando desde la observación a la acción pedagógica en la práctica inicial: Aprender a enseñar con foco en el aprendizaje del alumnado [Moving from observation to pedagogical actions in initial field experiences: learning to teach with a focus on students' learning]. Estudios pedagógicos (Valdivia), 42(4), 49-68. https://dx.doi.org/10.4067/S0718-07052016000500004

Costa, I. (2020). Continuing teacher training in conflict mediation: A socio-educational strategy for the current school. [Unpublished master's thesis]. Lusophone University of Porto. http://hdl.handle.net/10437/10326 
Costa, E. P., \& Sá, S. (2019). Teacher narratives on the practice of conflict mediation. In A. Costa, L. Reis \& A. Moreira (Eds.), Computer supported qualitative research - New trends on qualitative research, 861 (pp. 156-169). Springer. https://doi.org/10.1007/978-3-030-014063_14

Costa, E. P., Torrego Seijo, J. C., \& Martins, A. M. (2018). Mediação escolar: A análise qualitativa da dimensão interpessoal/social de um projeto de intervenção numa escola TEIP [School mediation: A qualitative analysis of the interpersonal/social dimension of an intervention project in a TEIP school]. Revista Lusófona de Educação, 40, 111-126. https://doi.org/10.24140/issn.1645-7250.rle40.07

DeVoogd, K., Lane-Garon, P., \& Kralowec, C. A. (2016). Direct instruction and guided practice matter in conflict resolution and social-emotional learning. Conflict Resolution Quarterly, 33(3), 279-296. https://doi.org/10.1002/crq.21156

Geijsel, F., \& Meijers, F. (2005). Identity learning: The core process of educational change. Educational Studies, 31(4), 419-430. https://doi.org/10.1080/03055690500237488

Grant, M. J., \& Booth, A. (2009). A typology of reviews: an analysis of 14 review types and associated methodologies. Health Information and Libraries Journal, 26(2), 91-108. https://doi.org/10.1111/j.1471-1842.2009.00848.x

Guggenheim, A. (2019). Hope in the wobbles: Negotiations into, out of, and between critical dispositions. Equity \& Excellence in Education, 52(2-3), 298-311. https://doi.org/10.1080/10665684.2019.1647807

Hakvoort I., Lindahl J., \& Lundström, A. (2019). A Bibliometric review of approaches to address conflicts in schools: Exploring the intellectual base. Conflict Resolution Quarterly, 37(2), 123145. https://doi.org/10.1002/crq.21266

Hakvoort, I. (2010). The conflict pyramid: a holistic approach to structuring conflict resolution in schools. Journal of Peace Education, 7(2), 157-169. https://doi.org/10.1080/17400201.2010.498997

Harlanova E, Sivrikova, N., Bisembayeva, A., \& Moiseeva E. (2019). The interaction of formal and non-formal education in the formation of conflictological readiness of future teachers. CITISE, 5(22), 118-128. http://doi.org/10.15350/24097616.2019.5.11

Horsley, M., \& Bauer, K. (2010). Preparing early childhood educators for global education: The implications of prior learning. European Journal of Teacher Education, 33(4), 421-436. https://doi.org/10.1080/02619768.2010.509427

Ibarrola-García, S., Iriarte, C., \& Aznárez-Sanado, M. (2017). Self-awareness emotional learning during mediation procedures in the school context. Electronic Journal of Research in Educational Psychology, 15(1), 75-105. http://dx.doi.org/10.14204/ejrep.41.15175

Johnson, K. E., \& Dellagnelo, A. (2013). How 'sign meaning develops': Strategic mediation in learning to teach. Language Teaching Research, 17(4), 409-432. https://doi.org/10.1177/1362168813494126

Jovanovic, O., Simic, N., \& Rajovic, V. (2014). Students at risk: Perceptions of Serbian teachers and implications for teacher education. European Journal of Teacher Education, 37(2), 220 236. https://doi.org/10.1080/02619768.2013.858693

Kharlanova, E., Sokolova, N., \& Roslyakova, S. (2020). Scientific and methodological support of the conflictological training for future teachers: proactive modeling. Perspectives of Science and Education, 47(5), 102-121. https://doi.org/10.32744/pse.2020.5.7

Koshmanova, T., \& Ravchyna, T. (2010). Ukrainian teacher candidates develop dispositions of socially meaningful activity. International Journal of Educational Reform, 19(2), 107-127. https://doi.org/10.1177/105678791001900203

Lane-Garon, P., Ybarra-Merlo, M., Zajac, J., \& Vierra, T. (2005). Mediators and mentors: Partners in conflict resolution and peace education. Journal of Peace Education, 2(2), 183-193. https://doi.org/10.1080/17400200500173592

Martins, A. M., Machado, C., \& Furlanetto, E. C. (2016). Conflict mediation in schools: Between norms and teachers' perceptions. Cadernos de Pesquisa, 46(161), 566-592. https://dx.doi.org/10.1590/198053143798 
Moher, D., Liberati, A., Tetzlaff, J., \& Altman, D. G. (2009). Preferred reporting items for systematic reviews and meta-analyses: The PRISMA statement. PLoS Medicine, 6(7), 1-6. https://doi.org/10.1371/journal.pmed.1000097

Munn, Z., Peters, M., Stern, C., Tufanaru, C., McArthur, A., \& Aromataris, E. (2018). Systematic review or scoping review? Guidance for authors when choosing between a systematic or scoping review approach. BMC Medical Research Methodology, 18(143), 1-7. https://doi.org/10.1186/s12874-018-0611-x

Romanova, E., Rychikhina, E., Bershedova, I., Nabatnikova, L., \& Akhtyan, A. (2019). Competencia en el ámbito de conflictos de profesores como una condición de la interacción positiva en el ambiente educativo [Conflictological competence of a teacher as a condition of positive interaction in the educational environment]. Espacios, 40(31), 29-39. https://www.revistaespacios.com/a19v40n31/19403129.html

Tirado Morueta, R., \& Conde Vélez, S. (2015). Organización del aula de convivencia y efectos en la reducción de conductas contrarias [Coexistence classroom organization and effects in reducing conduct contrary]. Revista Espanola de Orientacion y Psicopedagogia, 26(2), 75-89. https://doi.org/10.5944/reop.vol.26.num.2.2015.15217

Torrecilla Sánchez, E., Rodríguez Conte, M., Olmos Miguelañez, S., \& Torrijos Fincias, P. (2017). Determinantes de la satisfacción de los profesores de secundaria, como indicador de calidad de un programa formativo en resolución de conflictos [Determinants of the satisfaction of secondary school teachers, as an indicator of quality of a training program in conflict resolution]. Revista Complutense de Educación, 28(2), 517-535. https://doi.org/10.5209/rev_RCED.2017.v28.n2.49572

Willey, C., \& Magee, P. (2016). Clinical experiences and mediational activities in urban teacher preparation: Learning and critical consciousness. Global Education Review, 3(4), 107-126. https://doaj.org/article/c0bf88045c774ba7b5a4700f300794f9

Yssel, N., Beilke, J. R., Church, K. L., \& Zimmerman, J. S. (2001). CoRE: A conceptual model for incorporating conflict resolution into teacher education. The Teacher Educator, 36(4), 295305. https://doi.org/10.1080/08878730109555273 